\title{
POLITIKK
}

FOKUS: 25 ÅR MED EØS

\section{EØS-avtalens betydning for norsk regelutvikling - passiv resepsjon av fremmed rett eller aktiv europapolitikk?}

\author{
Liv Monica Stubholt og Marius Torstensen Grønnbakk \\ Advokatfirmaet Selmer
}

\begin{abstract}
Sammendrag
Artikkelen tar utgangspunkt i EØS-avtalens relative anonymitet i samfunnet fra dag til dag. Avtalens fundamentale innvirkning på regeldannelsen er lite synlig. Forfatterne trekker paralleller til integrasjonen av romerretten i europeisk rett på 1100-tallet og til dagens moderne, digitaliserte samfunn der løpende oppdatering av programvare er mer er en nødvendighet enn et reelt valg.
\end{abstract}

Nøkkelord: EØS-avtalen • implementering • suverenitet • EØS i Norge

Norske handels- og eksportinteresser hadde mye å si for at Norge undertegnet EØS-avtalen, selv om analysen av EØS alltid vil være forbundet med diskusjonen om norsk medlemskap i EU. Da medlemskapsspørsmålet ble avklart, ble EØS vår tilknytningsform til EU.

Implementering av nytt regelverk som springer ut av EØS-avtalen, skjer løpende og uten stor oppmerksomhet. Spørsmålet om Norges reelle handlefrihet under EØS-avtalen, herunder Norges (og de øvrige EFTA-EØS-landenes) rett etter avtalen til å unnlate å vedta nytt regelverk (reservasjonsretten), har likevel blusset opp i konkrete saker. Noen eksempler er innføring av matsminkedirektivet og postdirektivet. Men den grunnleggende diskusjonen om hvilken samlet og akkumulert betydning EØS-avtalen har for norsk regelutvikling og lovgivningens innhold, er

\footnotetext{
^Kontaktinformasjon: Liv Monica Stubholt, e-post: L.Stubholt@selmer.no

(C2019 Liv Monica Stubholt og Marius Torstensen Grønnbakk. This is an Open Access article distributed under the terms of the Creative Commons Attribution 4.0 International License (http://creativecommons.org/licenses/by/4.0/), allowing third parties to copy and redistribute the material in any medium or format and to remix, transform, and build upon the material for any purpose, even commercially, provided the original work is properly cited and states its license.

Citation: Liv Monica Stubholt og Marius Torstensen Grønnbakk (2019). EØS-avtalens betydning for norsk regelutvikling-passiv resepsjon av fremmed rett eller aktiv europapolitikk? Internasjonal Politikk, 77(4): 350-357. http://dx.doi.org/10.23865/intpol. v77.1981
} 
mer sjelden. Det er riktignok i dag en gryende konflikt i deler av norsk arbeidsliv om hvorvidt Norge på alvor bør vurdere å trekke seg ut av EØS-samarbeidet. Deler av samfunnslivet mener at vi burde tilslutte oss unionen fullt ut. En siste skare vektlegger ensidig EØS-avtalen. Det er likevel en betydelig grad av materialtretthet i det offentlige ordskiftet om EØS. Det tar riktignok fyr en sjelden gang i konkrete saker, som for eksempel i spørsmålet om Norges tilslutning til ACER. Men vi er raskt tilbake til normalen. Det kan ha sammenheng med avtalens tilblivelse.

EØS-avtalen er avtalen som ingen egentlig ønsket da den ble unnfanget. Da den ble fremforhandlet, så partene for seg at den ville vare i kun få år, fra 1993 til 1995, for i 1995 skulle Norge inn i EU. Først da folkeavstemningen i 1994 satte en stopper for det, ble EØS et varig alternativ for Norges tilknytning til EU. I utgangspunktet ville alle som forhandlet avtalen, ha blitt meget overrasket over at vi i år kan feire 25-årsjubileum. Det kan kanskje bidra til å forklare noen av de langsiktige svakhetene ved avtalen, ikke minst de demokratiske mangler ved at en så stor del av vår lovgivning initieres utenfor landets grenser. En midlertidig konstruksjon som EØS i utgangspunktet var, har ikke det samme behovet for å ta høyde for det langsiktige perspektivet.

Etter 25 år bør det være likevel være mulig å si noe mer om hvorvidt Norge har vært tjent med EØS som et premiss for store deler av norsk regelutvikling, eller om vi i realiteten ofrer for mye av Norges suverenitet og autonomi på lovgivningens område.

\section{EØS virker uten å synes}

EØS-avtalens påvirkning på norsk regelverksutvikling er stor og giennomgripende. Den sentrale utfordringen er at påvirkningen kan være vanskelig å få øye på, med mindre man selv jobber praktisk eller teknisk med implementering, eller med å påvirke EU når det gjelder utvikling av nye regler.

Avtalens mekanismer har nemlig fellestrekk med et operativsystem for datamaskiner og nettverk. Etter at EØS er «installert», så virker avtalen stort sett uten at det lenger synes. Et operativsystem styrer alt på en datamaskin, herunder prosessor, minne og lagring. Når man tar i bruk en datamaskin, tar man det derfor for gitt at alt fungerer. Man behøver ikke å huske på å oppdatere innholdet (programvaren), fordi operativsystemet bringer deg alle de oppdateringer som er påkrevet. Du får derfor stadig tilbud om oppdateringer. Skal man være à jour og ha glede av maskinen, har man i realiteten ikke noe valg.

EØS-avtalen bringer på tilsvarende måte nye «oppdateringer» etter at EØS som operativsystem først er installert. Dersom EØS-komiteen bestemmer at en oppdatering av regelverket skal innlemmes i EØS-avtalen, er det formelt og juridisk helt opp til EØS-landene å implementere bestemmelsen(e) nasjonalt. Men i praksis er det en høy terskel for å si nei. Dersom vi skal være oppdatert, henge med resten av EU og fortsatt fullt ut ta del i de markeder som EØS-avtalen gir oss tilgang til, må vi tilpasse oss. Om vi ikke følger utviklingen, kan vi kanskje sammenligne oss med Mac-brukere, 
som trenger en hel rekke adaptere for å ta del i det gode selskap. EØS-avtalen hjemler klart bruk av reservasjonsretten. De som hevder at reservasjonsretten ikke er reell, tar feil. Men det politiske samarbeidet mellom EFTA, EØS og EU tåler antakelig ikke veldig mye før irritasjonen over «adapter behovet» blir for stor.

\section{Med signaturen ble Norge en del av EUs indre marked}

EØS-avtalen handler i utgangspunktet om det indre marked. Mye av det EU holder på med, er ikke EØS-relevant, men EØS-avtalen har vist seg å påvirke mye, samtidig som Norge unilateralt har valgt å tilslutte seg EUs byråer og politiske og faglige samarbeid på mange områder. Utgangspunktet var dog klart: «Det er en hovedoppgave for Regjeringen å bidra til et forpliktende økonomisk samarbeid slik at internasjonal handel og økonomisk samkvem underlegges forutsigbare og like vilkår basert på felles regler» (St.prp. 1991-92: 9). EØS-avtalen skulle gi det norske samfunn uhindret tilgang til det europeiske indre marked og fritt omløp av varer og tjenester, kapital og arbeidstakere. De fire friheter skulle bringe sysselsetting, eksport og vekst.

Felles regler og standarder bidrar åpenbart til å styrke og utvikle en moderne økonomi. Et overordnet og felles regelsett og konkurranse på like vilkår gir insentiv for virksomheter i alle faser, kanskje særlig for virksomheter i en oppstarts- eller overgangsfase. Et felles konkurransereglement og kontroll og tilsyn fra myndighetene i henhold til felles standarder og regler stimulerer effektivitet og konkurransekraft. EØS skulle stimulere eksport og import. Fasiten etter 25 år er at grensekryssende handel fortsatt er økende, og EU er Norges viktigste marked. Ikke bare bringer EØS et toll- og avgiftsregime som gir store deler av norsk eksport markedsadgang. Det bidrar også til at utenlandske virksomheter kan satse i Norge fordi de vet hvilke regler som gjelder. Felles regler og standarder kommer også innbyggere til gode. «Roam like home» er et godt eksempel fra det siste tiåret. 15. juni 2017 trådte EUs felleseuropeiske regler om bruk av mobiltelefon på reise i utlandet i kraft. Reglene innebærer at brukerne ikke skal betale ekstra for samtaler, SMS eller datatrafikk når de er på reise i andre EU-EØS-land. Reglene ble tatt inn i EØS-avtalen og gjennomført i norsk rett, med betydelige besparelser for alle mobilbrukere.

\section{EØS-avtalen kopler oss til et tog i fart}

Formålet med EØS var å sikre Norge full adgang til EUs indre marked. Ved forhandlingene av EØS visste partene at regelverket i EU for det indre marked ville og måtte endre seg. Reglene ville raskt gå ut på dato uten en dynamisk mekanisme i avtalen. EØSavtalen forutsetter altså løpende og dynamisk etterlevelse. Dette er kanskje EØSavtalens mest karakteristiske trekk. En strøm av oppdateringer er nødvendig (Sverdrup, 2019).

God og fortsatt markedsadgang gjennom EØS-avtalen er basert på forutsetningen om vi endrer oss i samme takt når EU utvikler nye regler. Dette gjør rettshomogenitet (altså like regler i hele EØS-territoriet) til et svært sentralt premiss for 
EØS-samarbeidet. Rettshomogeniteten i EØS-avtalen var viktig for at EU skulle oppleve at avtalen fungerte etter deres behov, og for at norsk næringsliv skulle kunne nyte godt av tilgang til markedene. EØS-avtalen bevarer Norges suverenitet når det gjelder å vedta nye regler, samtidig som det er avtalemekanismer som forutsetter at partene bestreber seg på å opprettholde like og forutsigbare regler. Det ligger også en politisk forventning i samarbeidet med EU under EØS-avtalen om at det vil skje.

Norge inngikk med dette en avtale som kan sammenliknes med en lisensavtale til et operativsystem for regelutvikling, noe som skulle bli styrende for vår rettstenking og innholdet i vår lovgivning. Mekanismen bevarte Norges juridiske og konstitusjonelle suverenitet. Det gjorde det mulig å ta EØS i bruk for langsiktig organisering av vårt forhold til EU etter at det ble nei til medlemskap. De langsiktige, akkumulerte konsekvensene er likevel i mindre grad diskutert.

Tilsvarende ser vi nå, 25 år etter at vi ikke fullt ut så hvilket omfang dette samarbeidet skulle få. I stortingssalen ved vedtakelsen i 1992 var man under behandlingen for eksempel overbevist om at verken differensiert arbeidsgiveravgift, norske skatteregler eller landbrukssektoren ville bli berørt. Det viste seg ikke å stemme på noe punkt. I dag er innflytelsen så betydelig at analogien til programvare og operativsystem kanskje kan suppleres med en historisk parallell, nemlig utbredelsen av romerretten og resepsion av antikkens romerske rett, som vi diskuterer nedenfor.

\section{EØS som rettslig resepsjon av EU-retten}

Rettslig resepsjon er betegnelsen på innføringen av fremmed rett i en annen rettskultur. Resepsjon av annen rettsorden kan høres ut som om man er utsatt for en imperialistisk erobring. Men den kanskje mest kjente rettslige resepsjonen er resepsjonen av romerretten i begynnelsen av middelalderen i Europa. Den var en ønsket og villet opphenting fra historien. På samme vis valgte også Stortinget, etter nøye politiske og samfunnsøkonomiske overveielser, å slutte seg til EUs indre marked. Derved vedtok man en systematisk EU-påvirkning av norsk rett fremover, gjennom å ratifisere EØS-avtalen.

Men resepsjonen av romerretten innebar ikke, som EØS-avtalen, en løpende forpliktelse til å arbeide for rettshomogenitet. Sånn sett er EØS-avtalen kanskje en enda mer inngripende resepsjon av fremmed rett i vår rettskultur, fordi den også har det dynamiske elementet for fremtiden, og fordi den derved påvirker lovgivningen fremover direkte. Resepsjonen av romerretten var en vitenskapelig øvelse som startet ved universitetene. Der kunne romerretten rolig studeres uten at den forandret seg. EFTA-EØS-landene, herunder Norge, må forholde seg til en EU-rett i rask utvikling.

Den opprinnelige romerretten handlet i utgangspunktet også om politiske planer og ambisjoner. Den østromerske keiser Justinian (keiser 527-565) ønsket å gjenerobre de vestlige deler av Romerriket. Han hadde tro på at loven var viktig for dette formålet og fikk samlet og utgitt en lovsamling. Denne lovsamlingen fikk 


\section{Liv Monica Stubholt og Marius Torstensen Grønnbakk}

langt senere navnet Corpus Juris Civilis. Interessen for denne lovsamlingen gjenoppsto i europeisk rettsutvikling på 1100-tallet. De rettslærde begynte å interessere seg for keiser Justinians lov, og man begynte å studere den ved de nye universitetene i Europa. Dette ble utgangspunktet for det som kalles resepsionen av antikkens romerske rett. Resepsjonen av den romerske rett skapte nye juridiske strukturer i middelalderen, som fortsatt preger juridisk tankesett og tradisjoner i Europa i dag. Dette la grunnlaget for utformingen av moderne rett slik den er i dag.

Dag Michalsen, nå dekan for juridisk fakultet på UiO, peker på at den romerske rettens styrke var at den ikke var territorielt avgrenset eller begrenset til et geografisk eller nasjonalt område. I tillegg ble romerretten ansett som en universell rett som gjaldt i kraft av en iboende fornuft og vitenskapelig og kulturell autoritet. Romersk rett hadde derfor en særskilt normativ karakter som gjorde den både dynamisk og fleksibel. Den var skapt gjennom flere hundre års systematisk og vitenskapelig bearbeiding og utvikling på læresteder rundt om i Europa, og dernest integrert i lovgivningen, domstolene og det praktiske liv i kontrakter (Michalsen, 2011, s. 187).

Denne beskrivelsen har likhetstrekk med den europeiske rett og den utbredelsen den har fått, ut over sitt geografiske område. EU-retten har innflytelse langt ut over EU gjennom sine bilaterale og regionale avtaler med naboland og andre i interessesfæren, gjennom sitt forhold til land som kandiderer til å bli EU-medlemmer, og ikke minst gjennom EØS-avtalen. EU-retten har også en normativ tilnærming til for eksempel samfunnets behov for frihet for og regulering av markedene. EU er også basert på ideen om at frie markeder og god markedsregulering har en iboende fornuft, og at fri bevegelse, fri konkurranse, transparente og forutsigbare anskaffelsesregler og regulering av offentlig støtte realiserer store verdier og sunne samfunn. EU-retten er også, som romerretten, designet for å være internasjonal og egnet til å krysse grenser.

Corpus Juris Civilis var et samlebegrep for rettskilder fra det romerske riket, og lovsamlingen var ment som et verktøy for å oppnå homogenitet og politisk samarbeid og styrke. Dette har likhetstrekk med samlebegrepet «acquis communautaire», som brukes i EU-retten. Dette omfatter EUs regelverk fra 1958 til i dag, slik det til enhver tid er. Dette gjelder alle EU-traktater, forordninger, direktiver, rettsavgjørelser, uttalelser og resolusjoner, internasjonale avtaler samt grunnleggende rettighetsbestemmelser og prinsipper i traktatene. Acquis communautaire er et innbegrep som fanger opp en regelmasse i stadig utvikling, men med definerbare rammer for hva som omfattes. Alle EU-stater, gamle så vel som nye, må akseptere den til enhver tid eksisterende acquis communautaire og implementere mekanismer for å slutte seg til fremtidige elementer. Ifølge EU-retten skal acquis communautaire ha forrang fremfor nasjonal rett ved eventuell regelkonflikt, og den skal også ha direkte virkning for EU-medlemsland.

Det felleseuropeiske regelverket som startet med romerretten, og som eksisterer uavhengig av geografisk tilhørighet, er med på å danne grunnlaget for vår rettskildetenkning. Kanskje det felles opphavet også er med på å forklare vår avslappede 
holdning til å integrere EU-retten fortløpende. Selv om vi etter EØS-retten ikke er rettslig forpliktet til å implementere nye rettsakter, ligger det i avtalens formål, mekanismer og logikk at vi gjør dette for å sikre juridisk regelkonformitet. Når denne regelutviklingen også oppleves som kjent og relevant, blir terskelen for å avvike fra den forutsatte prosessen høy.

EU-domstolen skal behandle juridiske spørsmål relatert til EU-regelverket, og domstolen er som sådan ytterligere et verktøy for å sikre rettshomogenitet innenfor EU slik at fellesskapsretten fortolkes på samme måte i samtlige medlemsland. I EU-landene er dommene rettskraftige, og EU-domstolen er på mange måter en pådriver for rettsutviklingen innen EU. EFTA-domstolen er en egen domstol som er opprettet under EØS-avtalen, og den skal avgjøre saker under EØS-avtalen. EFTA-domstolen skal være uavhengig av EU-domstolen, men må likevel forholde seg til at den forvalter et regelverk der EØS-avtalen har en målsetting om å nå frem til og opprettholde en lik fortolkning og anvendelse av EØS-avtalen og EU-regelverket. Når EFTA-domstolen får forelagt en sak, forventes den å se hen til EU-domstolens praksis. EFTA-domstolen vil derfor bli et verktøy for å implementere den resepsjonen av EU-rett i EØS-EFTA-landene som EØS-avtalen vil oppnå.

\section{Aktiv europapolitikk}

EØS-avtalen gir ikke EØS-landene stemmerett i EU, men dette betyr også et handlingsrom som ikke EU-medlemmer har. Vi har beslutningskompetanse når det gjelder hvordan vi velger å gjennomføre et regelverk som er vedtatt på EU-nivå, og som senere er blitt en del av EØS-avtalen.Vi kan velge tilpassede løsninger i noen tilfeller, særlig der reglene ikke er fullt ut EØS-relevante. Og vi kan reservere oss mot implementeringen av et bestemt regelverk (reservasjonsretten).

Men EØS er mer enn juss, og påvirkning av EUs regelproduksjon kan skje på andre måter enn ved å utøve stemmerett. Norge har handlingsrom til å påvirke beslutningsprosesser i EU/EØS. I Meld. St. 5 (2012-2013) heter det at «Regjeringen ønsker å bruke handlingsrommet i forvaltningen av avtalene. Det innebærer at Regjeringen ønsker å bruke de muligheter Norge har til å påvirke regelverksutviklingen i EØS og på Schengen-området. Det innebærer også at Regjeringen ønsker å bruke de muligheter som foreligger ved gjennomføring av regelverket i norsk rett». Og videre at «Norges avtaler med EU gir størst mulighet for medvirkning i politikk- og regelverksutforming i EU i en tidlig fase. Med tidlig fase menes forberedelsen av Kommisjonens forslag og de innledende diskusjonene i Rådet og Europaparlamentet» (Meld. St. 5 2012-2013: 37).

De fleste regjeringer har siden EØS-avtalens ikrafttreden definert en ambisjon om en aktiv europapolitikk - det vil si å bruke handlingsrommet aktivt fremfor å være et passivt medlem av fellesskapet. Dagens regjering skriver på sine hjemmesider at «for å lykkes med å påvirke viktige beslutninger må Norge være tydeligere, tyngre og tidligere ute i europapolitiske spørsmål». I Meld. St. 5 (2012-2013) gir 


\section{Liv Monica Stubholt og Marius Torstensen Grønnbakk}

Utenriksdepartementet uttrykk for det samme standpunktet, nemlig at «som nedfelt i Soria-Moria-erklæringene vil Regjeringen føre en aktiv europapolitikk og arbeide målrettet for å ivareta norske interesser overfor EU» og at det for Norges vedkommende er «viktig at EØS-samarbeidet er kjennetegnet ved robusthet, fleksibilitet og gjensidig ansvar» (Meld. St. 5 2012-2013).

Norge bruker en del ressurser på å følge med på regelutviklingen i EU. Norge har for eksempel i snitt mellom 50 og 60 utsendte nasjonale eksperter i Europakommisjonen og tilknyttede byråer av interesse for Norge. I tillegg inviteres Norge inn $\mathrm{i}$ arbeidsgrupper $\mathrm{i}$ forbindelse med utredninger og annet forarbeid til lovgivningsprosessen. Det hevdes at der vi har høy kompetanse, blir vi ofte lyttet til. Man skal ikke kimse av norsk innflytelse på regelutvikling i Europakommisjonen når det gjelder våre paradegrener. Men man skal heller ikke undervurdere at det fort er de samme områder der det er reelle motsetningsforhold mellom Norge og EU, som for eksempel energisektoren og utviklingen av nordområdene. Spørsmålet blir da om aktiv europapolitikk avhjelper de betydelige og prinsipielle utfordringene med EØSavtalens demokratiske underskudd.

\section{De demokratiske svakheter ved et EØS med automatiske oppdateringer}

Demokratisk forankring er et fundament for lovgivningen i de fleste vestlige land. Det kan sies at EØS-rettens påvirkning på lovgivning mangler fullgod demokratisk forankring. Normalt vil dette karakteriseres som en svakhet ved systemet, men for EØS-avtalens overlevelse har dette kanskje vist seg å være en av dens styrker. Dens usynlighet har ført den under radaren og har også gitt den en sterk og nær automatisk gjennomslagskraft i nasjonale lovgivningsprosesser. Europautredningen (NOU 2012:2) konkluderte langt på vei med at EØS-avtalens mål om et forpliktende økonomisk samarbeid, basert på fire friheter som skulle bringe sysselsetting, eksport og vekst, er oppnådd. Men den problematiserte også noen politiske konsekvenser, herunder når det gjelder demokratisk forankring:

\footnotetext{
Samlet sett er det store demokratiske svakheter ved den norske tilknytningsformen til EU og de virkninger den har for det politiske liv i Norge. Gjennom EØS, Schengen og de andre avtalene har Norge forpliktet seg til å overta politikk og regler fra en organisasjon der man ikke er medlem og ikke har stemmerett. Forutsetningene for norsk politisk representasjon er meget begrenset, og det samme gjelder mulighetene for å kontrollere og ansvarliggjøre de organene og personene som utformer den politikken og de reglene som binder Norge (NOU 2012:2, s. 835).
}

Dette er en oppsummering som vi mener står seg. Sitatets nesten brutale beskrivelse av svakhetene ved EØS gjør likevel at man undrer seg hvordan det har seg at det ikke er en betydelig større EØS-slitasje i det norske samfunn etter 25 år enn det er.

Vi lever med EU under EØS-avtalen som vi lever med moderne teknologi. Det er vanskelig å si nei til nye EØS-regler. Tilsvarende er det lite aktuelt å utøve den 
formelle adgangen vi har til å si nei til oppdatering av datamaskiner, mobiltelefoner og apper.Vi ofrer noe (for eksempel personvern for våre data) for bekvemmeligheten som følger med ny teknologi. Vi liker det nødvendigvis ikke, men vår vurdering er at fordelen er større enn ulempene. Vår holdning til EØS-avtalen bærer kanskje preg av samme pragmatisme.

\section{Om forfatterne}

Liv Monica Stubholt er forretningsadvokat og partner i Advokatfirmaet Selmer. Hun har lang fartstid med EØS-spørsmål. Hun var del av utvalget som vurderte grunnlovmessigheten av Schengen-traktaten, og hun var nestleder i Europautredningen. I tillegg har hun adressert en rekke problemstillinger i EØS-avtalen i praksis, giennom sin karriere som politiker, næringslivsleder og rådgiver for næringslivet.

Marius Torstensen Grønnbakk er advokatfullmektig i Advokatfirmaet Selmer med utdanning fra Universitetet i Tromsø. Han har vært vit.ass. på K. G. Jebsensenter for havrett og har LL.M i Law of the Sea. Han har et stort engasjement for internasjonal rett og samarbeid.

\section{Referanser}

Michalsen, D. (2011). Rett - en internasjonal historie. Oslo: Pax.

NOU 2012: 2. (2012). Utenfor og innenfor. Norges avtaler med EU. Oslo: Norges offentlige utredninger. Hentet fra https://www.regjeringen.no/no/dokumenter/nou-2012-2/id669368/

Meld. St. 5. (2012-13). EØS-avtalen og Norges øvrige avtaler med EU. Oslo: Utenriksdepartementet.

St.prp. nr. 100 (1991-92). Om samtykke til ratifikasjon av Avtale om Det europeiske økonomiske samarbeidsområde (EØS). Undertegnet i Porto 2. mai 1992. Oslo: Utenriksdepartementet.

Sverdrup, U. (2019). 25 år med stabilitet og forutsigbarhet. Internasjonal Politikk, 77(4).

\section{Abstract in English \\ The EEA Agreement's Significance for Norwegian Lawmaking - Passive Reception of Foreign Law or Pro-active European Policy?}

The article's starting point is the relative anonymity of the EEA Agreement in day to day society. This renders its fundamental impact on the legislation partially occluded. The authors draw on parallels both to the reception of Roman law into European law in the 12th century and to the digitalisation of modern society, where the decision to update software is a virtual rather than a real choice.

Keywords: EEA Agreement • implementation • sovereignty $\cdot$ EEA in Norway 